\title{
PENGARUH PENGERINGAN TERHADAP KADAR AIR DAN KUALITAS BOLU DARI TEPUNG SORGUM (Sorghum bicolor L)
}

\author{
Gita Indah Budiarti ${ }^{1, *}$, Irfan Sya'bani ${ }^{1}$, Muhammad Arshal Alfarid ${ }^{1}$ \\ ${ }^{1}$ Teknik Kimia, Fakultas Teknologi Industri, Universitas Ahmad Dahlan, Jl. Ringroad Selatan, Yogyakarta \\ *E-mail: gita.indah@che.uad.ac.id
}

\begin{abstract}
ABSTRAK
Sorgum merupakan serealia bernutrisi tinggi yang potensial untuk subtitusi terigu. Pemanfaatan sorgum saat ini hanya untuk pakan ternak. Penepungan pada sorgum selain untuk menambah masa simpan juga untuk mengurangi kadar tanin. Salah satu penentu kualitas tepung adalah kadar air. Penelitian ini bertujuan untuk mengetahui pengaruh suhu dan waktu pengeringan kadar air pada tepung sorgum yang dimanfaatkan sebagai campuran pada pembuatan bolu. Hasil penelitian modifikasi tepung sorgum yang didapat dari $2 \mathrm{~kg}$ tepung sorgum sosoh menjadi $1,4 \mathrm{~kg}$ tepung sorgum termodifikasi adalah $70 \%$. Nilai kadar air pada suhu tepung sorgum termodifikasi tersebut yang mendekati kadar air tepung terigu SNI yaitu pada waktu pengeringan 5 jam dengan suhu $80^{\circ} \mathrm{C}$ dan $90^{\circ} \mathrm{C}$ yaitu sebesar $13,8095 \%$ dan $14,6154 \%$. Perbandingan komposisi penggunnaan tepung sorgum dan tepung terigu terhadap kareakteristik bolu yang optimum atau sesuai terhadap karakteristik bolu SNI adalah $50 \%$ tepung sorgum dan $50 \%$ tepung terigu.
\end{abstract}

Kata kunci: Sorghum, kadar air, bolu, pengeringan, terigu

\begin{abstract}
Sorghum is a cereal with high nutritional potential as a substitute for wheat. The current use of sorghum is only for animal feed. Flouration on sorghum is not only to increase the shelf life but also to reduce the tannin content. One of the determinants of flour quality is water content. This study aims to determine the effect of temperature and drying time on moisture content in sorghum flour which is used as a mixture in making sponge cake. The results of the modification of sorghum flour obtained from $2 \mathrm{~kg}$ of fine sorghum flour to $1.4 \mathrm{~kg}$ of modified sorghum flour is $70 \%$. The value of the water content at the temperature of the modified sorghum flour which is close to the water content of the SNI wheat flour is at a drying time of 5 hours with a temperature of $80^{\circ} \mathrm{C}$ and $90^{\circ} \mathrm{C}$, namely $13.8095 \%$ and $14.6154 \%$, respectively. Comparison of the composition of the use of sorghum flour and wheat flour on the characteristics of the optimum sponge cake or according to the characteristics of SNI cake is 50\% sorghum flour and 50\% wheat flour.
\end{abstract}

Keywords: Sorghum, moisture content, sponge cake, drying, flour

PENDAHULUAN

Sorgum (Sorghum bicolor L. Moench) merupakan tanaman serealia sumber karbohidrat dari famili

Gramineae (rumput-rumputan).

Pemanfaatan sorgum di Indonesia 
masih sangat terbatas. Selama ini sorgum hanya dijadikan sebagai pakan ternak, padahal sorgum memiliki potensi yang besar untuk dikembangkan di Indonesia. Kandungan nutrisi sorgum dibandingkan dengan tanaman serealia lainnya seperti padi, jagung, dan beras (Griebel dkk., 2019). Kandungan nutrien dalam sorgum bervariasi tergantung pada varietas, umumnya mengandung protein kasar 8,9 $10,48 \%$, lemak $2,5-3,7 \%$, serat kasar $1,2-3,01 \%$, abu $1,2-6,94 \%$, pati dan gula $61,24-76,6 \%$ dengan berat kering (BK) sekitar 88,94-93,31\%. Hal ini membuktikan bahwa sorgum memiliki potensi untuk dijadikan sumber pangan alternatif (Haryani, Lakzita, \& Sari, 2021).

Selama ini sorgum sudah diolah menjadi produk tepung untuk dimanfaatkan dalam berbagai pengolahan makanan. Proses pengolahan sorgum menjadi tepung sorgum merupakan langkah untuk meningkatkan nilai ekonomisnya (Suarni, 2016). Penepungan pada sorgum selain menambah nilai ekonomis juga mengurangi kandungan tanin dalam sorgum. Tanin merupakan zat antinutrisi yang menghambat penyerapan nutrisi (Gunawan, Pranata, \& Swasti, 2021; Ochieng, Owino, Kinyuru, Mburu, \& Gicheha, 2020).

Kadar protein sorgum memiliki kandungan protein yang setara dengan tepung terigu dengan kandungan patinya lebih tinggi dari tepung terigu. Sorgum merupakan bahan pangan yang cukup potensial untuk dikembangkan menjadi tepung (Wulandari, Sukarminah, Mardawati, \& Furi, 2019).
Tepung sorgum dapat digunakan sebagai bahan substitusi terigu, dalam pembuatan kue kering hingga taraf 50$80 \%$, kue basah $40-50 \%$, roti $20-25 \%$ dan mi $15-20 \%$. Beberapa penelitian telah dilakukan untuk memanfaatkan tepung sorgum menjadi berbagai produk seperti kue kering, kue basah, roti, mie, nasi instant (Paramita, 2019; Suarni, 2016). Pemanfaatan tepung sorgum sebagai campuran pada pembuatan makanan di Indonesia sudah banyak dikembangkan, salah satunya pada produk bolu. Bolu merupakan makanan ringan yang digemari masyarakat terutama anak-anak. Untuk meningkatkan kegunaan tepung sorgum sebagai bahan substitusi, perlu diketahui batas maksimal penambahan tepung sorgum ke dalam adonan sehingga masih menghasilkan produk olahan dengan kualitas yang baik (Setiarto \& Widhyastuti, 2016).

Kadar air menentukan umur simpan suatu bahan pangan. Kadar air dapat menentukan kualitas tepung. Kadar air dapat dikurangi dengan adanya proses pengeringan (Budiarti, Wulandari, Mutmaina, \& Sulistiawati, 2020).

Penelitian ini bertujuan untuk mengetahui pengaruh suhu dan waktu pengeringan kadar air pada tepung sorgum yang dimanfaatkan sebagai campuran pada pembuatan bolu.

\section{METODE}

Alat yang digunakan untuk pembuatan tepung sorgum termodifikasi menggunakan penggilingan padi, baskom, saringan, kain blacu, timbangan, penggilingan beras, cawan dan oven. Dengan bahan baku yang digunakan berupa biji sorgum, dan air. 
Alat yang digunakan untuk pembuatan bolu menggunakan mixer, mangkok, baskom, timbangan, dan sendok. Dengan bahan baku yang digunakan tepung terigu, telur, tepung sorgum, margarine, soda kue dan gula.

Pembuatan sorgum sosoh diawali dengan pembersihan biji sorgum dari material selain biji sorgum, selanjutnya biji sorgum yang telah bersih tersebut degrading, hal ini bertujuan untuk mendapatkan biji sorgum dengan ukuran yang seragam. Setelah grading, dilakukan proses conditioning, dan selanjutnya biji sorgum disosoh dengan alat sosoh. Tahap perendaman dilakukan dengan cara memrendam sorgum sosoh dengan larutan aquades selama 8 jam pada suhu kamar. Setelah masa perendaman selesai kemudian air rendaman dibuang (ditiriskan). Sorgum sosoh yang telah direndam kemudian digiling menggunakan penggiling yang dialiri air sambil disaring menggunakan saringan. Sorgum yang sudah digiling basah kemudian disaring menggunakan kain blacu dan kemudian press menggunakan mesin press hidrolik. Selanjutnya mengeringkan sorgum dengan oven dengan waktu 4 jam, 5 jam, 6 jam, dengan suhu $60^{\circ} \mathrm{C}, 70^{\circ} \mathrm{C}$, $80^{\circ} \mathrm{C}, \quad 90^{\circ} \mathrm{C}$ untuk setiap waktu pengovenannya. Sorgum yang sudah kering lalu dihitung berat dan analisa kadar air menggunakan metode thermogravimetri sesuai SNI 3751:2009. Metode ini menghitung berat air dengan basis kering. Sampel dimasukkan ke oven kemudian ditimbang setiap 60 menit.

Tepung dengan kadar air menggunakan thermo gravimetri terbaik digunakan untuk membuat bolu. Untuk membuat bolu dilakukan beberapa langkah, yaitu yang pertaama adalah mempersiapan bahan baku dan alat yang akan digunakan, kedua penimbangan bahan, ketiga mencampur seluruh bahan dengan tepung sorgum termodifikasi dan tepung terigu sesuai perbandingan selama \pm 15 menit dengan menggunakan mixer, dan yang terakhir pengovenan selama 4 jam dengan suhu $90^{\circ} \mathrm{C}$. Bolu yang telah jadi selanjutnya dianalisis warna, tekstur dan ketebalannya

Bolu akan diamati warna, tekstur dan daya kembang menggunakan uji organoleptik (panca indra) sesuai SNI 3751:2009.

\section{HASIL DAN PEMBAHASAN}

\section{Pengaruh Lama dan Suhu Pengeringan Terhadap Yield}

Dalam pengolahan sorgum menjadi tepung dilakukan percobaan terhadap sorgum yang sudah disosoh sebanyak 2 $\mathrm{kg}$ selama 8 jam menggunakan aquades yang kemudian akan dikeringkan di oven agar menjadi tepung sorgum. Berdasarkan hasil penelitian berat total tepung sorgum yang didapat dari pengeringan $2 \mathrm{~kg}$ sorgum sosoh adalah sebanyak 1,4 kg. Pengurangan berat dari $2 \mathrm{~kg}$ menjadi 1,4 kg karena proses pengeringan sorgum. Untuk mencari yield dari tepung sorgum adalah dengan cara yaitu membagi nilai nilai berat bahan yang digunakan dengan nilai berat tepung yang didapatkan. Maka nilai yield tepung sorgum adalah $70 \%$. Yield tergantung pada jenis sorgum dan proses yang digunakan (Lyons dkk., 2019).

\section{Pengaruh Lama dan Suhu Pengeringan Terhadap Kadar Air}

Pengaruh lama dan suhu pengeringan terhadap kadar air ini dilakukan dengan cara membandingkan nilai kadar air yang didapat berdasarkan perbedaan lama dan suhu. Hasil analisis pengaruh lama dan suhu pengeringan terhadap kadar air disajikan pada Gambar 1. 


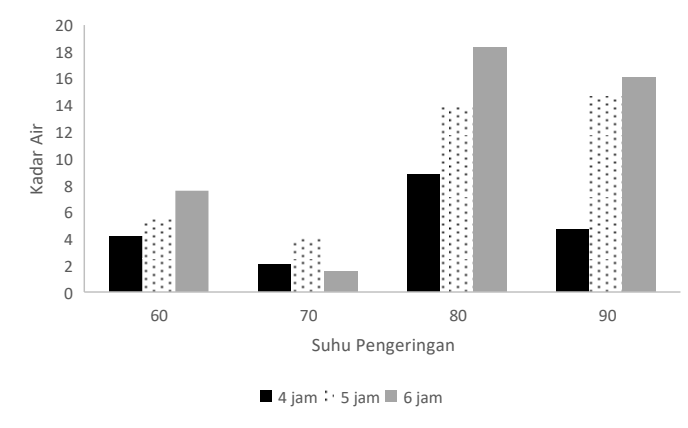

Gambar 1. Data Lama dan Suhu Pengeringan terhadap Kadar Air

Dari Gambar 1 dapat dilihat nilai kadar air analisis untuk masing masing waktu dan suhu, kemudian bandingkan kadar air analisis dengan kadar air tepung terigu menurut SNI (2009) maksimum $\quad 14,5 \%$. Setelah dibandingkan dengan standar kadar air untuk tepung terigu nilai kadar air terbaik diperoleh pada waktu pengeringan 6 jam dengan suhu $70^{\circ} \mathrm{C}$ sebesar $1,5 \%$. Oleh karena itu waktu dan suhu yang paling optimum untuk digunakan dalam proses pengeringan tepung sorgum adalah 6 jam dengan suhu $70^{\circ} \mathrm{C}$. Meskipun variasi waktu dan suhu yang lain sudah memenuhi syarat SNI tepung terigu, namun tidak serendah suhu $70^{\circ} \mathrm{C}$, waktu pengeringan 6 jam. Semakin rendah kadar air yang diperoleh akan menambah umur simpan tepung (Budiarti \& Sulistiawati, 2019; Budiarti, Sulistiawati, Septiani, \& Septianindi, 2021).

Berdasarkan pengaruh waktu dan suhu pengeringan terhadap kadar air, semakin tinggi suhu pengeringan maka semakin cepat terjadi penguapan, sehingga kandungan air di dalam bahan semakin rendah. Semakin lama suatu bahan kontak langsung dengan panas, maka kandungan air juga akan semakin rendah (Sari, 2016). Pengeringan berpengaruh terhadap kadar air, hal ini dikarenakan pengeringan yang cukup lama menyebabkan jumlah air yang teruapkan lebih banyak sehingga kadar air dalam tepung berkurang (Ndukwu, Dirioha, Abam, \& Ihediwa, 2017). Semakin tinggi suhu dan semakin lama waktu pengeringan yang digunakan untuk mengeringkan suatu bahan, maka air yang menguap akan semakin banyak. Namun untuk hasil kadar air yang tinggi dapat disebabkan oleh beberapa kemungkinan seperti penyimpanan yang kurang baik dan faktor lain khususnya pada proses pengeringan. Proses pengeringan tersebut akan dipengaruhi oleh luas permukaan bahan, ketebalan hamparan bahan yang dikeringkan, suhu pengeringan juga beberapa perlakuan yang tidak sesuai selama proses pengolahan (Nuraeni, Yudi, \& Iyan, 2018). Ketidaksesuaian hasil kadar air dengan teori mungkin disebabkan perbedaan ketebalan bahan yang dikeringkan.

\section{Pengaruh Pebandingan Komposisi Penggunaan Tepung Sorgum dan Tepung Terigu terhadap Karakteristik Bolu}

Pada penelitian kali ini hasil tepung sorgum termodifikasi digunakan untuk membuat bolu.Tepung sorgum yang digunakan adalah pengeringan 6 jam dengan suhu $70^{\circ} \mathrm{C}$. Pembuatan bolu yang dilakukan yaitu menggunakan dua formulasi yaitu tepung sorgum termodifikasi dan tepung terigu. Pembuatan bolu ini dilakukan dengan cara membandingkan komposisi antara tepung sorgum dan tepung terigu dalam pembuatannnya. Perbandingan yang digunakan antara tepung sorgum dan tepung terigu secara berurutan sebesar 0\%:50\%, 50\%:50\%, 75\%:25\% dan full $100 \%$ tepung sorgum. Hal ini dilakukan bertujuan untuk membandingkan karakteristik bolu tersebut dari segi warna, tekstur dan ketebalan bolu. 
Tabel 2. Perbandingan Kerakteristik Warna, Tekstur Dan Ketebalan Bolu

\begin{tabular}{|c|c|c|c|c|}
\hline No & $\begin{array}{c}\% \\
\text { Tepung } \\
\text { sorgum }\end{array}$ & Warna & Tekstur & Ketebalan \\
\hline 1 & $0 \%$ & $\begin{array}{c}\text { Coklat } \\
\text { kekuningan }\end{array}$ & Lembut & Mengembang \\
\hline 2 & $50 \%$ & Coklat & Lembut & Mengembang \\
\hline 3 & $75 \%$ & $\begin{array}{c}\text { Coklat } \\
\text { kehitaman }\end{array}$ & Kenyal & $\begin{array}{c}\text { Sedikit } \\
\text { mengembang }\end{array}$ \\
\hline 4 & $100 \%$ & $\begin{array}{c}\text { Coklat } \\
\text { kehitaman }\end{array}$ & keras & Bantet \\
\hline
\end{tabular}

Hasil perbandingan karakteristik bolu yang diperoleh dapat dilihat pada Tabel 2. perbandingan karakteristik warna, tekstur dan ketebalan bolu. Bolu yang dibuat dengan komposisi full $100 \%$ tepung terigu memiliki karakteristik warna coklat kekuningan, tekstur yang lembut dan ketebalan yang mengembang. Untuk bolu dengan komposisi 50\% tepung sorgum dan 50\% tepung terigu memiliki karakteristik warna coklat, tekstur lembut dan ketebalan mengembang. Untuk bolu dengan komposisi $75 \%$ tepung sorgum dan $25 \%$ tepung terigu memeliki karakteristik warna coklat kehitaman, tekstur yang kenyal dan ketebalan sedikit mengembang. Sedangkan untuk bolu dengan komposisi full $100 \%$ tepung sorgum memiliki karakteristik warna coklat kehitaman, tekstur keras, dan ketebalan yang bantet.

Dari hasil perbandingan di atas terlihat bahwa semakin banyak tepung sorgum termodifikasi yang digunakan dalam membuat bolu maka warna dari bolu tersebut akan semakin gelap, teksturnya akan semakin keras dan ketebalannya semakin bantet/padat. Hal ini disebabkan pada sorgum tidak mengandung gluten yang mempengaruhi daya kembang bolu. (Sari, 2016).

\section{SIMPULAN}

Dari penelitian yang dilakukan maka dapat disimpulkan bahwa nilai rendemen yang didapat dari penggunaan $2 \mathrm{~kg}$ biji sorgum menjadi tepung sorgum sebanyak $1.4 \mathrm{~kg}$ adalah $70 \%$. Nilai kadar air pada suhu tepung sorgum termodifikasi tersebut yang mendekati kadar air tepung terigu SNI yaitu pada waktu pengeringan 6 jam dengan suhu $70^{\circ} \mathrm{C}$ sebesar $1,5 \%$. Perbandingan komposisi penggunnaan tepung sorgum dan tepung terigu terhadap kareakteristik bolu yang optimum atau sesuai terhadap karakteristik bolu SNI adalah 50\% tepung sorgum dan $50 \%$ tepung terigu.

\section{DAFTAR RUJUKAN}

Budiarti, G. I., \& Sulistiawati, E. (2019). Aplikasi hydrogen rich water pada modifikasi tepung kentang dengan pengering gelombang mikro sebagai alternatif substitusi gandum. Elkawnie: Journal of Islamic Sciences and Technology, 5(2), 128-138. https://doi.org/10.22373/ekw.v5i2. 4704

Budiarti, G. I., Sulistiawati, E., Septiani, N., \& Septianindi, W. (2021). Karakteristik Tepung Kulit Pisang Modifikasi Menggunakan Hydrogen Rich Water, 5(1), 2832.

Budiarti, G. I., Wulandari, A., Mutmaina, S., \& Sulistiawati, E. (2020). Modified Pumpkin Flour Using Hydrogen Rich Water with a Microwave. Chemica, 7(1), 19-24.

Griebel, S., Webb, M. M., Campanella, O. H., Craig, B. A., Weil, F., \& Tuinstra, M. R. (2019). The alkali spreading phenotype in Sorghum 
bicolor and its relationship to starch gelatinization. Journal of Cereal Sciences, 86(September 2018), 41-47. https://doi.org/10.1016/j.jcs.2019.0 1.002

Gunawan, A., Pranata, F. S., \& Swasti, Y. R. (2021). Kualitas Muffin Dengan Kombinasi Tepung Sorgum ( Sorghum Bicolor ) Dan Tepung Kacang Merah ( Phaseolus Vulgaris ) The Quality Of Muffin With A Combination Of Sorghum Flour (Sorghum Bicolor) And Red Bean Flour (Phaseolus Vulgaris). Jurnal Teknologi Hasil Pertanian, 14(1), 11-19.

Haryani, K., Lakzita, P. R., \& Sari, P. P. (2021). Modifikasi Tepung Sorgum Dengan Metode Fermentasi Menggunakan Bakteri Asam Laktat Lactobacillus Bulgaricus. Inovasi Teknik Kimia, 6(1), 11-16.

Lyons, S. E., Ketterings, Q. M., Godwin, G. S., Cherney, D. J., Cherney, J. H., Amburgh, M. E. Van, Kilcer, T. F. (2019). Optimal harvest timing for brown midrib forage sorghum yield, nutritive value, and ration performance. Journal of Dairy Science, 102(8), 7134-7149.

https://doi.org/10.3168/jds.201916516

Ndukwu, M. C., Dirioha, C., Abam, F. I., \& Ihediwa, V. E. (2017). Heat and mass transfer parameters in the drying of cocoyam slice. Case Studies in Thermal Engineering, 9(November 2016), 62-71. https://doi.org/10.1016/j.csite.2016 .12 .003

Nuraeni, L., Yudi, G., \& Iyan, S. (2018). Pengaruh Suhu dan Lama
Pengeringan terhadap

Karakteristik Tepung Terubuk (Saccharum edule Hasskarl). Universitas Pasundan.

Ochieng, B. A., Owino, W. O., Kinyuru, J. N., Mburu, J. N., \& Gicheha, M. G. (2020). Effect of low tannin sorghum based feeds on broiler meat nutritional quality. Journal of Agriculture and Food Research, 2(October), 100078. https://doi.org/10.1016/j.jafr.2020. 100078

Paramita, O. (2019). Pengaruh Teknik Perendaman pada Pembuatan Tepung Sorgum Merah (Bicolor L) Ditinjau dari Kualitas Butter Cookies, 7(1), 22-30.

Sari, L. P. (2016). Pemanfaatan Tepung Sorgum Putih sebagai Bahan Subtitusi dalam Pembuatan Sus Songgobuwono (SOBUKOCAN) dan Bolu Kukus (BOUTRICAN). Universitas Negeri Yogyakarta.

Setiarto, R. H. B., \& Widhyastuti, N. (2016). Penurunan Kadar Tanin Dan Asam Fitat Pada Tepung Sorgum Melalui Fermentasi Rhizopus oligosporus, Lactobacillus plantarum dan Saccharomyces cerevisiae [ Reduction of Tannin and Phytic Acid on Sorghum Flour by using Fermentation of Rhizopus oligosporus, L. Berita Biologi, 149-157.

Suarni. (2016). Peranan Sifat Fisikokimia Sorgum Dalam Diversifikasi Pangan Dan Industri Serta Prospek Pengembangannya. Jurnal Litbang Pertanian, 35, 99110. https://doi.org/10.21082/jp3.v35n3 .2016.p99-110

Wulandari, E., Sukarminah, E., 
Mardawati, E., \& Furi, L. (2019). Profil Gelatinisasi Tepung Sorgum Putih Termodifikasi A -Amilase [ Pasting Properties of White Sorghum Flour Modified by $\alpha$ Amylase ]. Jurnal Teknologi Dan
Industri Pangan, 30(2), 173-179. https://doi.org/10.6066/jtip.2019.3 0.2 .173 